\title{
PENGARUH JARAK TANAM DAN PEMBERIAN DOSIS PUPUK KANDANG SAPI TERHADAP PERTUMBUHAN DAN HASIL BAWANG MERAH (Allium ascalonicum L.)
}

\author{
The Influence Of Plant Distance and Cow Manure Dosage \\ to Shallot Growth (Allium ascalonicum L.)
}

\author{
Muhammad Juwanda* dan Wadli \\ Universitas Muhadi Setiabudi (UMUS) Brebes \\ Jl. P. Diponegoro KM 2 Pesantunan Kec. Wanasari, Kab. Brebes, Jawa Tengah \\ Telp. (0283)6199000 / Fax. (0283)6199001 \\ *Alamat Korespondensi: muhammad.juwanda@gmail.com
}

\begin{abstract}
ABSTRAK
Penelitian ini bertujuan untuk upaya peningkatan produksi dan hasil budidaya tanaman bawang merah yang berwawasan lingkungan dengan pemanfaatan pupuk kandang sapi dan pengaturan jarak tanam. Penelitian dilaksanakan selama 8 bulan dari bulan Januari sampai dengan Agustus 2015.Penelitian dilakukan di lahan sawah Brebes, Kabupaten Brebes, jenis tanah alluvial dengan ketinggian tempat kurang lebih $50 \mathrm{~m}$ dpl. Penelitian ini merupakan percobaan faktorial 4 × 3 dengan rancangan lingkungan adalah rancangan acak kelompok. Faktor pertama adalah Jarak Tanam: $\mathrm{J} 1=20 \mathrm{~cm} \times 20 \mathrm{~cm}, \mathrm{~J} 2=20 \mathrm{~cm} \times 15 \mathrm{~cm}, \mathrm{~J} 3=20 \mathrm{~cm} \times 10 \mathrm{~cm}$. Faktor yang kedua adalah takaran pupuk kandang sapi yaitu $\mathrm{K} 0=0$ ton/ha, $\mathrm{K} 1=10$ ton/ha, $\mathrm{K} 2=20$ ton/ha, K3 = 30 ton/ha. Karakter pertumbuhan dan hasil bawang merah diamati pada penelitian ini. Data hasil pengamatan dianalisis dengan uji $\mathrm{F}$ untuk mengetahui keragamannya dan apabila ada perbedaan nyata dilanjutkan dengan DMRT dengan tingkat kesalahan 5\%. Hasil penelitian menunjukkan bahwa hasil umbi segar dan kering bawang merah per hektar tertinggi diperoleh pada tanaman dengan perlakuan jarak tanam $20 \times 15 \mathrm{~cm}$ dengan hasil 20,56 t/ha (umbi segar) dan 18,63 $\mathrm{t} /$ ha (umbi kering).
\end{abstract}

Kata kunci: bawang merah, jarak tanam, pupuk kandang sapi, pertumbuhan dan hasil

\section{ABSTRACT}

This reseacrh purpose was to know the effect of plant distance and application of cow manure on growth and yield of shallot by which sustainable for agriculture production.. This research was done within 8 months since January until August 2015. This research was done in Brebe with characters of alluvial soil and place hight is less than $50 \mathrm{~m}$ above sea level. This research arranged by factorial with first factor of plant distance viz. $J 1=20 \mathrm{~cm} \times 20 \mathrm{~cm}, J 2=20 \mathrm{~cm} \times 15 \mathrm{~cm}, J 3=20 \mathrm{~cm} \times 10 \mathrm{~cm}$ and second factor of cow manure dosage viz. K0 $=0$ to/ha, K2 $=20$ ton/ ha, K3 = 30 ton/ha. The character of growth and yield of shallots was observed in this study.Data of observing result analized by $F$ test and it will be continued by DMRT $p=5 \%$ if there was significant difference. Research result showed that the highest wet tuber and dry shallot per hectare mostly found on plant distance $20 \times 15 \mathrm{~cm}$ with the result of $20.56 \mathrm{t} / \mathrm{ha}$ and $18.63 \mathrm{t} / \mathrm{ha}$, respectively.

Keywords: shallot, plant distance, cow manure, growth and yield

\section{PENDAHULUAN}

Bawang merah (Allium ascalonicum

L.) merupakan salah satu komoditas sayuran unggulan yang sejak lama telah diusahakan petani secara intensif. Bawang merah merupakan tanaman umbi yang dibudidayakan dibeberapa negara tropis
(Woldetsadik, 2003). Indonesia merupakan salah satu negara tropis yang terletak di Asia tenggara. Bawang merah memiliki nilai ekonomi yang tinggi, sehingga pengusahaannya telah menyebar di hampir semua provinsi di Indonesia. Prospek pengembangan bawang merah sangat baik 
ditinjau dari permintaan yang terus meningkat sejalan meningkatnya jumlah penduduk. Bawang merah merupakan salah satu komoditas hortikultura yang penting bagi masyarakat baik secara ekonomis ataupun kandungan gizinya. Bawang merah biasanya digunakan sebagai bumbu masak sehari-hari maupun obat tradisional. Permintaan bawang merah semakin lama semakin meningkat sejalan dengan meningkatnya jumlah penduduk (Juwanda, 2011).

Menurut Sumarni dan Hidayat (2005), pada tahun 2003 total pertanaman bawang merah petani Indonesia sekitar 88.029 ha dengan rata-rata hasil 8,7 ton/ha. Produktivitas hasil bawang merah tersebut dipandang masih rendah, karena potensi hasil yang dapat dicapai sekitar 20 t/ha. Salah satu penyebab rendahnya hasil bawang merah adalah produktivitas lahan yang semakin rendah. Penyebab rendahnya produktivitas lahan sawah di Indonesia diantaranya adalah karena pola penanaman jarak tanam yang kurang tepat dan kandungan bahan organik tanah yang semakin rendah di lahan persawahan.

Dalam suatu pertanaman sering terjadi persaingan antar tanaman maupun antara tanaman dengan gulma untuk mendapatkan unsur hara, air, cahaya, matahari maupun ruang tumbuh. Salah satu upaya yang dapat dilakukan untuk mengatasinya adalah dengan pengaturan jarak tanam. Dengan tingkat kerapatanyang optimum maka akan diperoleh indeks luas daun (ILD) yang optimum dengan pembentukan bahan kering yang maksimum. Jarak tanam yang rapat akan meningkatkan daya saing tanaman terhadap gulma karena tajuk tanaman menghambat pancaran cahaya ke permukaan lahan sehingga pertumbuhan gulma menjadi terhambat, disamping juga laju evaporasidapat ditekan. Namun pada jarak tanam yang terlalu sempit mungkin tanamanbudidaya akan memberikan hasil yang relatif kurang karena adanya kompetisiantar tanaman itu sendiri. Oleh karena itu dibutuhkan jarak tanam yang optimumuntuk memperoleh pertumbuhan yang optimal (Nurlaili, 2010). Menurut Nugrahini (2013), pengaturan jarak tanam berpengaruh terhadap pertumbuhan dan hasil tanaman bawang merah.

Pemupukan adalah usaha pemberian atau penambahan bahan-bahan atau zat-zat kepada kompleks tanah-tanaman untuk melengkapi keadaan makanan atau unsur hara dalam tanah yang tidak cukup terkandung di dalamnya. Banyak dilaporkan bahwa penggunaan pupuk anorganik atau kimia buatan seperti pupuk nitrogenurea dan ZA secara terus menerus menjadi tidak efisien dan dapat mengganggu keseimbangan sifat tanah sehingga menurunkan produktivitas lahan dan mempengaruhi produksi. Tanah 
menjadi bantat/keras serta kehidupan mikroorganisme tanah menjadi terganggu akibatnya tanah menjadi kurang produktif dan kurang subur akibat dari penggunaan pupuk nitrogen (kimia buatan) yang terus menerus. Menurut Roidah (2013), penggunaan input kimia dengan dosis yang tinggi dan jangka waktu yang lama menyebabkan terjadinya akumulasi residu bahan kimia berbahaya, menurunnya kualitas fisika dan kimia tanah yang berdampak pada penurunan kualitas lingkungan.

Produksi yang tinggi akan berlanjut apabila didukung oleh berbagai komponen yang saling sinergi. Salah satu komponen tersebut adalah lingkungan tanah. Menurut Sumarno (2007), lingkungan tanah dapat mendukung produksi yang berkesinambungan apabila kualitas tanah dapat dijaga dari kerusakan. Salah satu upaya untuk mengendalikan kerusakan tanah adalah dengan meningkatkan penggunan bahan-bahan organik dalam bentuk pupuk organik didalam melakukan budidaya tanaman. Menurut Lasmini dkk. (2015), pemupukan dapat diberikan dengan menggunakan pupuk organik dan pupuk kimia buatan, pupuk organik atau bahan organik dimaksudkan untuk meningkatkan efisiensi penggunaan pupuk kimia buatan. Mengingat pentingnya fungsi dan peranan bahan organik bagi tanah serta makin intensifnya penggunaan pupuk kimia oleh petani maka sangatlah penting untuk mulai memperhatikan usaha pengembalian bahan organik ke tanah sehingga produktivitas tanah tetap terjaga dengan baik.

Pemberian pupuk organik dapat memperbaiki sifat-sifat tanah seperti sifat fisik, kimia dan biologi tanah. Bahan organik merupakan perekat butiran lepas, sumber hara tanaman dan sumber energi dari sebagian besar organisme tanah. Pemberian pupuk organik dapat meningkatkan daya larut unsur P, K, Ca dan $\mathrm{Mg}$, meningkatkan C-organik, kapasitas tukar kation, kapasitas tanah memegang air, menurunkan kejenuhan $\mathrm{Al}$ dan bulk density (BD) tanah. Salah satu bahan organik yang dapat diaplikasikan pada lahan sawah adalah pupuk kandang sapi (Juwanda, 2011). Penggunaan bahan organik berupa kotoran sapi secara ekonomis murah, mudah diperoleh sehingga relatif mudah dijangkau oleh petani. Pemberian pupuk organik (kandang sapi) yang dikombinasikan dengan aplikasi pengaturan jarak tanam diharapkan dapat memberikan hasil yang optimal bagi pertumbuhan dan produksi tanaman bawang merah. Penelitian ini bertujuan untuk upaya peningkatan produksi dan hasil budidaya tanaman bawang merah yang berwawasan lingkungan dengan pemanfaatan pupuk kandang sapi dan pengaturan jarak tanam. 


\section{METODE}

Penelitian dilaksanakan dari bulan Januari sampai dengan Agustus 2015. Penelitian dilakukan di lahan sawah Brebes, Kabupaten Brebes, jenis tanah alluvial dengan ketinggian tempat kurang lebih 50 $\mathrm{m}$ dpl. Bahan yang digunakan dalam penelitian ini meliputi bibit bawang merah varietas Bima Brebes. Bahan organik yang diperlukan adalah pupuk kandang sapi. Pupuk kimia buatan antara lain Urea, ZA, SP 36 dan $\mathrm{KCl}$, dan pestisida.

Penelitian ini merupakan percobaan faktorial $4 \quad x \quad 3$ dengan rancangan lingkungan adalah rancangan acak kelompok. Faktor pertama adalah jarak tanam: $\mathrm{J} 1=20 \mathrm{~cm} \times 20 \mathrm{~cm}, \mathrm{~J} 2=20 \mathrm{~cm} \times 15$ $\mathrm{cm}, \mathrm{J} 3=20 \mathrm{~cm} \times 10 \mathrm{~cm}$. Faktor yang kedua adalah takaran pupuk kandang sapi yaitu $\mathrm{K} 0$ $=0$ ton/ha, $\mathrm{K} 1=10$ ton $/$ ha, $\mathrm{K} 2=20$ ton/ha, $\mathrm{K} 3=30$ ton/ha. Kombinasi yang diperoleh sebanyak 12 perlakuan, setiap perlakuan diulang tiga kali. Data hasil pengamatan dianalisis dengan uji $\mathrm{F}$ untuk mengetahui keragamannya dan apabila ada perbedaan nyata dilanjutkan dengan DMRT dengan tingkat kesalahan 5\%.

Pelaksanaan penelitian, meliputi pengolahan tanah sempurna menggunakan cangkul dengan kedalaman sekitar $40 \mathrm{~cm}$. Selanjutnya, dibuat kotak-kotak bedengan berukuran 2 x 1,5 m sebanyak 36 petak. Jarak antar bedengan $50 \mathrm{~cm}$ berupa saluran drainase dengan kedalaman 0,75 $\mathrm{m}$.
Pemberian pupuk dasar meliputi pupuk kandang sapi sesuai perlakuan yaitu dengan dosis:0 t/ha, 10 t/ha (3 kg/petak), 20 t/ha (6 $\mathrm{kg} /$ petak), dan $30 \mathrm{t} / \mathrm{ha}$ (9 kg/petak). Selain itu juga diberikan pupuk P (SP36) dengan dosis $250 \mathrm{~kg} / \mathrm{ha}$. Pupuk dasar diaplikasikan 3 hari sebelum tanam.

Sebelum penanaman umbi bawang merah mula-mula dipotong sepertiga bagian ujungnya hingga bekas potongannya mengering. Jarak tanam yang dipakai sesuai dengan perlakuan $\mathrm{J} 1(20 \mathrm{~cm} \times 20 \mathrm{~cm}), \mathrm{J} 2$ $(20 \mathrm{~cm} \mathrm{x} 15 \mathrm{~cm})$ dan $\mathrm{J} 3(20 \mathrm{~cm} \times 10 \mathrm{~cm})$. Umbi bawang merah dimasukkan ke dalam lubang tanah sampai ujung umbi tampak rata dengan permukaan tanah.

Pemupukan lanjutan diberikan sesuai dengan dosis. Dosis pupuk nitrogen (N) 200 $\mathrm{kg} / \mathrm{ha}$, KCL $200 \mathrm{~kg} / \mathrm{ha}$. Masing-masing pupuk diberikan setengah dosis untuk pemupukan kedua dan ketiga. Pemeliharaan dalam penelitian ini meliputi: penyiraman dan pemberantasan hama dan penyakit digunakan pestisida sesuai dengan kebutuhan. Panen bawang merah dilakukan pada umur 56 hari setelah tanam.

Variabel yang diamati dalam penelitian ini adalah Tinggi tanaman $(\mathrm{cm})$, jumlah daun, jumlah umbi per tanaman, bobot segar tanaman per rumpun, bobot segar umbi per rumpun (g), bobot kering tanaman per rumpun (g), bobot kering umbi per rumpun $(\mathrm{g})$, volume umbi per rumpun $\left(\mathrm{cm}^{3}\right)$, bobot segar tanaman per sampel pada 
petak efektif (g), bobot umbi segar tanaman per sampel pada petak efektif (g), bobot kering tanaman per sampel pada petak efektif (g), bobot kering umbi per sampel pada petak efektif (g), dan hasil umbi segar dan kering tanaman $(\mathrm{t} / \mathrm{ha})$.

\section{HASIL DAN PEMBAHASAN}

Hasil analisis data menunjukkan bahwa jarak tanam berpengaruh terhadap seluruh variabel pengamatan terkecuali variabel tinggi tanaman, namun pemberian dosis pupuk kandang sapi tidak berpengaruh terhadap seluruh variabel pertumbuhan dan hasil yang diamati. Pengaruh jarak tanam terhadap pertumbuhan dan hasiltanaman bawang merah tidak tergantung dosis pupuk kandang sapi yang diberikan (Tabel 1).

Pemberian pupuk kandang sapi belum mampu meningkatkan karakter pertumbuhan dan hasil tanaman bawang merah, karena pupuk kandang belum dapat memperlihatkan manfaatnya pada satu kali masa tanam (Tabel 1). Manfaat pupuk kandang akan terlihat kurang lebih setelah dua / tiga kali masa tanam.Menurut Hardjowigeno (2010), perhitungan dosis pupuk kandang tidak bisa tepat dan respon tanaman terhadap pupuk sangat lambat dari pada pupuk buatan. Menurut Plaster (1997), kandungan nutrisi pada pupuk organik relatif rendah dan diserap oleh tanaman lebih lambat dibandingkan nutrisi pada pupuk buatan.

Tabel 1. Matrik Uji F data pengamatan pertumbuhan dan hasil bawang merah dengan perlakuan jarak tanam dan dosis pupuk kandang sapi

\begin{tabular}{|c|c|c|c|c|}
\hline No & Variabel Pengamatan & $\begin{array}{c}\text { Jarak } \\
\text { tanam } \\
(\mathrm{J})\end{array}$ & $\begin{array}{c}\text { Dosis } \\
\text { Pupuk } \\
\text { Kandang } \\
\text { Sapi (K) }\end{array}$ & $\mathrm{J} \times \mathrm{K}$ \\
\hline 1 & Tinggi tanaman $(\mathrm{cm})$ & th & th & $\operatorname{tn}$ \\
\hline 2 & Jumlah daun & $\mathrm{n}$ & tn & th \\
\hline 3 & Jumlah umbi & $\mathrm{n}$ & $\operatorname{tn}$ & $\operatorname{tn}$ \\
\hline 4 & Bobot segar tanaman per rumpun $(\mathrm{g})$ & $\mathrm{n}$ & $\operatorname{tn}$ & $\operatorname{tn}$ \\
\hline 5 & Bobot segar umbi per rumpun (g) & $\mathrm{n}$ & $\operatorname{tn}$ & $\operatorname{tn}$ \\
\hline 6 & Bobot kering tanaman per rumpun $(\mathrm{g})$ & $\mathrm{n}$ & $\operatorname{tn}$ & $\operatorname{tn}$ \\
\hline 7 & Bobot kering umbi per rumpun $(\mathrm{g})$ & $\mathrm{n}$ & $\operatorname{tn}$ & $\operatorname{tn}$ \\
\hline 8 & Volume umbi per rumpun (ml) & $\mathrm{n}$ & $\operatorname{tn}$ & $\operatorname{tn}$ \\
\hline 9 & Bobot segar tanaman per sampel pada petak efektif (g) & $\mathrm{n}$ & $\operatorname{tn}$ & $\operatorname{tn}$ \\
\hline 10 & Bobot kering tanaman per sampel pada petak efektif $(\mathrm{g})$ & $\mathrm{n}$ & tn & tn \\
\hline 11 & Bobot segar umbi per sampel pada petak efektif $(\mathrm{g})$ & $\mathrm{n}$ & tn & tn \\
\hline 12 & Bobot kering umbi per sampel pada petak efektif (g) & $\mathrm{n}$ & tn & tn \\
\hline 13 & Hasil umbi segar tanaman ( $\mathrm{t} / \mathrm{ha})$ & $\mathrm{n}$ & $\operatorname{tn}$ & $\operatorname{tn}$ \\
\hline 14 & Hasil umbi kering tanaman ( $\mathrm{t} / \mathrm{ha})$ & $\mathrm{n}$ & tn & $\operatorname{tn}$ \\
\hline
\end{tabular}

Keterangan: $\mathrm{n}=$ berbeda nyata menurut uji $\mathrm{F}$ pada $p=0.05, \mathrm{tn}=$ tidak berbeda nyata menurut uji F pada $p=0.05$ 
Tabel 2. Tinggi tanaman, jumlah daun, dan jumlah umbi dengan perlakuan jarak tanam dan dosis kandang sapi

\begin{tabular}{|c|c|c|c|}
\hline \multirow{2}{*}{ Perlakuan } & \multicolumn{3}{|c|}{ Variabel pengamatan } \\
\hline & Tinggi tanaman $(\mathrm{cm})$ & Jumlah daun & Jumlah umbi \\
\hline \multicolumn{4}{|l|}{ Jarak tanam } \\
\hline $\mathrm{J} 1(20 \times 20 \mathrm{~cm})$ & $40,84 \mathrm{a}$ & 45,18 a & 9,39 a \\
\hline $\mathrm{J} 2(20 \times 15 \mathrm{~cm})$ & $40,37 \mathrm{a}$ & 43,47 a & 9,05 a \\
\hline $\mathrm{J} 3(20 \times 10 \mathrm{~cm})$ & $37,91 \mathrm{a}$ & $22,16 \quad b$ & $5,10 \mathrm{~b}$ \\
\hline \multicolumn{4}{|c|}{ Pupuk Kandang Sapi } \\
\hline K0 (0 ton/ha) & 37,95 a & 37,6 & 8,28 a \\
\hline K1 (10 ton/ha) & 39,13 a & 37,45 a & 7,91 a \\
\hline K2 (20 ton/ha) & 40,10 a & $35,9 \quad \mathrm{a}$ & 7,68 a \\
\hline K3 (30 ton/ha) & $41,66 \mathrm{a}$ & 36,8 & $7,52 \mathrm{a}$ \\
\hline
\end{tabular}

Keterangan: Angka dalam kolom yang sama dengan kelompok perlakuan yang sama bila diikuti dengan huruf yang sama tidak berbeda nyata pada DMRT $(p=0.05)$.

Tabel 3. Karakter pertumbuhan dan hasil bawang merah dengan perlakuan jarak tanam dan dosis pupuk kandang sapi

\begin{tabular}{|c|c|c|c|c|c|}
\hline \multirow[b]{2}{*}{ Perlakuan } & \multicolumn{5}{|c|}{ Variabel pengamatan } \\
\hline & $\begin{array}{l}\text { Bobot segar } \\
\text { tanaman per } \\
\text { rumpun }(\mathrm{g})\end{array}$ & $\begin{array}{l}\text { Bobot segar } \\
\text { umbi per } \\
\text { rumpun }(\mathrm{g})\end{array}$ & $\begin{array}{c}\text { Bobot } \\
\text { kering } \\
\text { tanaman per } \\
\text { rumpun }(\mathrm{g})\end{array}$ & $\begin{array}{c}\text { Bobot } \\
\text { kering umbi } \\
\text { per rumpun } \\
(\mathrm{g})\end{array}$ & $\begin{array}{c}\text { Volume } \\
\text { umbi per } \\
\text { rumpun (ml) }\end{array}$ \\
\hline \multicolumn{6}{|l|}{ Jarak tanam } \\
\hline $\mathrm{J} 1(20 \times 20 \mathrm{~cm})$ & 90,87 a & $66,6 \quad a$ & $68,66 \mathrm{a}$ & $60,06 \mathrm{a}$ & $69,75 \mathrm{a}$ \\
\hline $\mathrm{J} 2(20 \times 15 \mathrm{~cm})$ & 86,22 a & $62,35 \mathrm{~b}$ & $66,4 \quad a$ & 57,56 a & $67,66 \mathrm{a}$ \\
\hline $\mathrm{J} 3(20 \times 10 \mathrm{~cm})$ & $29,14 \mathrm{~b}$ & $23,11 \mathrm{c}$ & $22,52 \mathrm{~b}$ & $20,72 \mathrm{~b}$ & $24,41 \mathrm{~b}$ \\
\hline \multicolumn{6}{|c|}{ Pupuk kandang sapi } \\
\hline $\mathrm{K} 0(0$ ton $/ \mathrm{ha})$ & 63,39 a & 46,45 a & $47,27 \mathrm{a}$ & $41,36 \mathrm{a}$ & $48,66 \mathrm{a}$ \\
\hline K1 (10 ton/ha) & 70,01 a & 50,86 a & 53,08 a & 46,33 a & 55 \\
\hline K2 (20 ton/ha) & 74,45 a & $56,17 \mathrm{a}$ & 58,98 a & 52,37 a & 59,44 a \\
\hline K3 (30 ton/ha) & 67,12 a & $49,28 \mathrm{a}$ & $50,77 \mathrm{a}$ & 44,39 a & 52,66 a \\
\hline
\end{tabular}

Keterangan: Angka dalam kolom yang sama dengan kelompok perlakuan yang sama bila diikuti dengan huruf yang sama tidak berbeda nyata pada DMRT.

Hasil penelitian menunjukan tanaman bawang merah dengan perlakuan jarak tanam $20 \times 15 \mathrm{~cm}$ mampu meningkatkan pertumbuhan tanaman, namun penambahan jarak tanam menjadi $20 \quad x \quad 20 \mathrm{~cm}$ peningkatan pertumbuhan tanaman bawang merah tidak sebaik tanaman dengan jarak tanam $20 \times 15 \mathrm{~cm}$ untuk variabel jumlah daun, jumlah umbi, bobot segar tanaman per rumpun, bobot kering tanaman per rumpun, bobot kering umbi per rumpun dan volume umbi per rumpun (Tabel 2 dan 3).

Tanaman bawang merah dengan perlakuan jarak tanam $20 \times 20 \mathrm{~cm}$ mampu menghasilkan pertumbuhan tanaman bawang merah yang terbaik dibandingkan perlakuan jarak tanam yang lain (Tabel 3 dan 4). Variabel untuk bobot segar umbi per rumpun, bobot segar tanaman per sampel pada petak efektif, bobot kering tanaman 
per sampel pada petak efektif, bobot segar umbi per sampel pada petak efektif, dan bobot kering umbi per sampel pada petak efektif untuk tanaman bawang merah dengan perlakuan jarak tanam $20 \times 20 \mathrm{~cm}$ memperoleh hasil yang terbanyak. Jarak tanam $20 \times 20 \mathrm{~cm}$ dengan populasi tanaman yang tidak terlalu rapat membuat tanaman bawang merah mudah untuk memperoleh nutrisi unsur hara di dalam tanah, persaingan akar tanaman dalam pengambilan unsur hara dan air di dalam tanah tidak kompetitif seperti pada perlakuan jarak tanam $20 \times 15 \mathrm{~cm}$ dan $20 \mathrm{x}$ $10 \mathrm{~cm}$. Pemberian pupuk Urea dan ZA didalam tanah yang mengandung unsur $\mathrm{N}$ tentunya lebih banyak terserap oleh tanaman per sampel dengan jarak tanam yang lebih lebar tentunya. Unsur $\mathrm{N}$ merupakan unsur makro yang sangat penting bagi pertumbuhan tanaman bawang merah. Metabolisme $\mathrm{N}$ merupakan faktor utama pertumbuhan vegetatif, batang, dan daun. Tanaman yang mendapatkan pasokan $\mathrm{N}$ cukup, pertumbuhan vegetatifnya baik tetapi terlalu banyak dapat menunda pembungaan dan pembentukan buah (Munawar, 2011).

Hasil pengamatan ke 1 sampai dengan ke 4 (Gambar 1 dan 2), menunjukan bahwa pertumbuhan bobot segar dan kering tanaman terbanyak diperoleh pada perlakuan jarak tanam 20 x $20 \mathrm{~cm}$. Mengingat juga bobot segar umbi dan kering umbi terbanyak diperoleh dari perlakuan $20 \times 20 \mathrm{~cm}$.

Tabel 4. Karakter pertumbuhan dan hasil per petak efektif dan per ha dengan perlakuan jarak tanam dan dosis pupuk kandang sapi

\begin{tabular}{|c|c|c|c|c|c|c|}
\hline \multirow[b]{2}{*}{ Perlakuan } & \multicolumn{6}{|c|}{ Variabel Pengamatan Pertumbuhan } \\
\hline & $\begin{array}{c}\text { Bobot } \\
\text { segar } \\
\text { tanaman } \\
\text { per } \\
\text { sampel } \\
\text { pada } \\
\text { petak } \\
\text { efektif } \\
\text { (g) }\end{array}$ & $\begin{array}{c}\text { Bobot } \\
\text { kering } \\
\text { tanaman } \\
\text { per } \\
\text { sampel } \\
\text { pada } \\
\text { petak } \\
\text { efektif }(\mathrm{g})\end{array}$ & $\begin{array}{c}\text { Bobot } \\
\text { segar } \\
\text { umbi per } \\
\text { sampel } \\
\text { pada } \\
\text { petak } \\
\text { efektif } \\
(\mathrm{g})\end{array}$ & $\begin{array}{c}\text { Bobot } \\
\text { kering } \\
\text { umbi per } \\
\text { sampel } \\
\text { pada } \\
\text { petak } \\
\text { efektif } \\
\text { (g) }\end{array}$ & $\begin{array}{c}\text { Hasil } \\
\text { umbi } \\
\text { segar per } \\
\text { ha (t/ha) }\end{array}$ & $\begin{array}{c}\text { Hasil } \\
\text { umbi } \\
\text { kering per } \\
\text { ha (t/ha) }\end{array}$ \\
\hline \multicolumn{7}{|l|}{ Jarak Tanam } \\
\hline $\mathrm{J} 1(20 \times 20 \mathrm{~cm})$ & $104,15 \mathrm{a}$ & 77,79 a & 74,93 a & 70,31 a & $17,53 \mathrm{~b}$ & $15,83 \mathrm{~b}$ \\
\hline $\mathrm{J} 2(20 \times 15 \mathrm{~cm})$ & $89,15 \mathrm{~b}$ & $67,74 \mathrm{~b}$ & $64,79 \mathrm{~b}$ & $61,38 \mathrm{~b}$ & 20,56 a & $18,63 \mathrm{a}$ \\
\hline $\mathrm{J} 3(20 \times 10 \mathrm{~cm})$ & $40,74 \mathrm{c}$ & $29,77 \mathrm{c}$ & $28,88 \mathrm{c}$ & $27,25 \mathrm{c}$ & $16,31 \mathrm{c}$ & $14,83 \mathrm{c}$ \\
\hline \multicolumn{7}{|c|}{ Pupuk Kandang Sapi } \\
\hline K0 (0 ton/ha) & $76,80 \mathrm{a}$ & 58,25 a & 55,72 a & 52,71 a & 16,75 a & 15,31 a \\
\hline K1 (10 ton/ha) & $77,20 \mathrm{a}$ & 58,27 a & 55,35 a & 51,99 a & $18,31 \mathrm{a}$ & $17,00 \mathrm{a}$ \\
\hline K2 (20 ton/ha) & $78,01 \mathrm{a}$ & 57,77 a & 55,99 a & 52,95 a & 18,62 a & $16,68 \mathrm{a}$ \\
\hline K3 (30 ton/ha) & $80,04 \mathrm{a}$ & 59,43 a & $57,74 \mathrm{a}$ & 54,26 a & 18,86 a & $16,73 \mathrm{a}$ \\
\hline
\end{tabular}

Keterangan: Angka dalam kolom yang sama dengan kelompok perlakuan yang sama bila diikuti dengan huruf yang sama tidak berbeda nyata pada DMRT. 


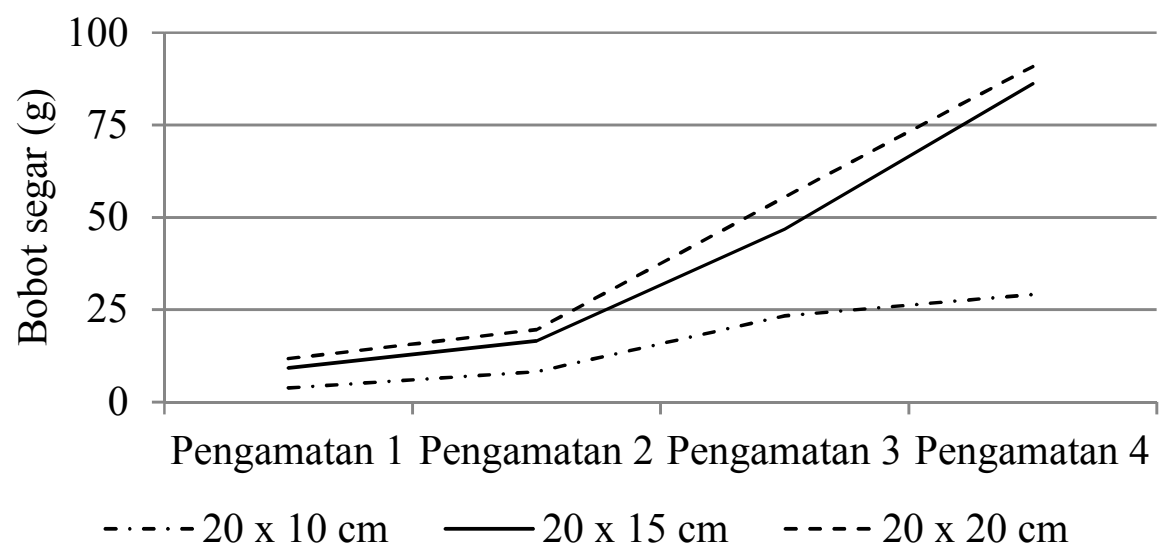

Gambar 1. Bobot Segar Tanaman Bawang Merah (g) pada perlakuan beberapa jarak tanam.

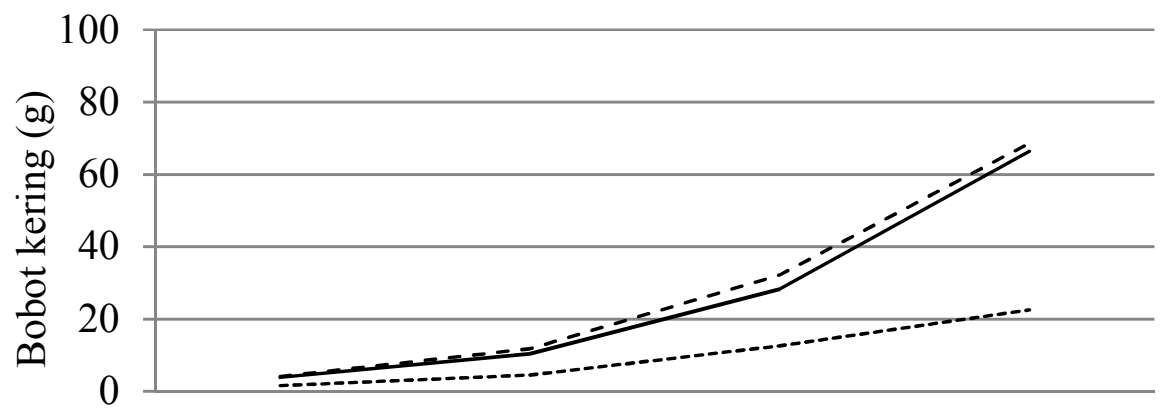

Pengamatan 1 Pengamatan 2 Pengamatan 3 Pengamatan 4

$----20 \times 10 \mathrm{~cm} \longrightarrow 15 \mathrm{~cm}---20 \times 20 \mathrm{~cm}$

Gambar 2. Bobot kering tanaman bawang merah (g) pada perlakuan beberapa jarak tanam.

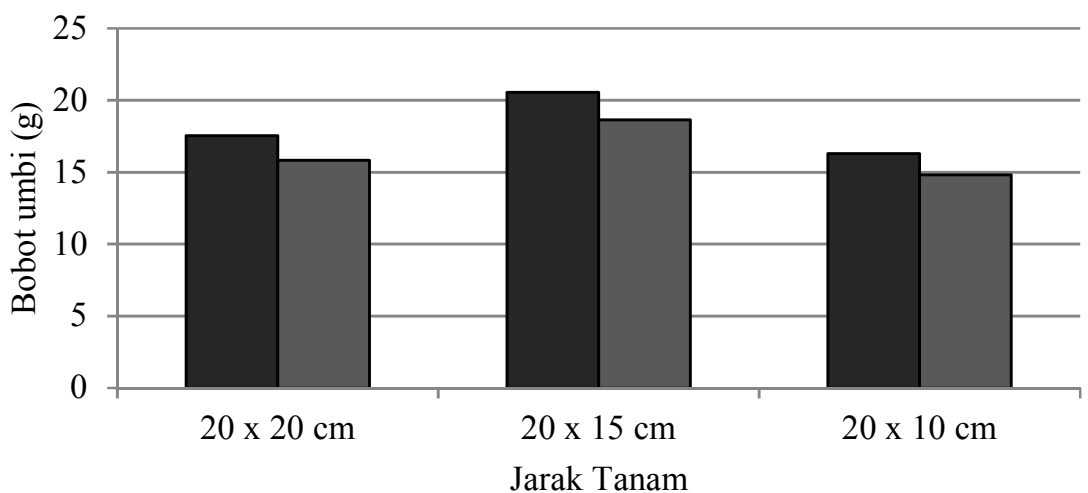

Hasil Umbi Segar (t/ha) aHasil Umbi Kering (t/ha)

Gambar 3. Hasil Umbi Segar dan Kering per Hektar (t/ha) pada perlakuan beberapa jarak tanam.

Pembentukan Umbi pada tanaman bawang merah dipengaruhi faktor-faktor lingkungan seperti fotoperiodesitas, suhu dan penggunaan bahan kimia. Pengaruh suhu pada pembentukan umbi akan lebih cepat pada suhu tinggi daripada suhu rendah (Zulkarnain, 2013). Pada perlakuan pemberian jarak tanam $20 \times 20 \mathrm{~cm}$ diduga memiliki suhu yang lebih tinggi dibandingkan dengan perlakuan jarak 
tanam yang lain karena kondisi pertanaman lebih longgar / tidak terlalu rapat sehingga perakaran lebih mudah untuk tumbuh dan berkembang sehingga tanaman bawang merah tumbuh dengan lebih baik. Sehingga pada perlakuan tersebut untuk pertumbuhan bobot kering umbi per rumpun pada petak efektif diperoleh bobot umbi segar maupun kering yang lebih banyak dibandingkan dengan yang lain.

Hasil penelitian (Tabel 4 dan Gambar 3) menunjukan bahwa perlakuan pada jarak tanam $20 \times 15 \mathrm{~cm}$ menghasilkan produksi bawang merah segar/kering (t/ha) yang terbanyak dibandingkan dengan perlakuan pada jarak tanam $20 \times 10 \mathrm{~cm}$ dan $20 \times 20$ cm. Hal ini disebabkan karena untuk pertanaman bawang merah dengan jarak tanam $20 \quad$ x $\quad 10 \quad \mathrm{~cm}$ menghasilkan pertumbuhan bawang merah yang relatif lebih kecil dibandingkan dengan perlakuan jarak tanam yang lain karena populasi pertanaman bawang yang lebih padat tidak menguntungkan untuk memperoleh nutrisi yang cukup dari dalam tanah sebagai akibat dari persaingan penyerapan unsur hara. Pertanaman dengan perlakuan jarak tanam $20 \times 20 \mathrm{~cm}$ memperoleh produksi hasil lebih rendah dibandingkan pertanaman dengan jarak tanam $20 \times 15 \mathrm{~cm}$ karena populasinya yang lebih sedikit walaupun memang pertumbuhannya lebih baik. Menurut Sumarni dkk. (2012), penanaman bawang merah dengan jarak tanam $20 \times 15 \mathrm{~cm}$ memberikan hasil produksi yang terbaik dengan bobot umbi kering 38,48 g/tanaman dibandingkan penanaman dengan jarak tanam $5 \times 20 \mathrm{~cm}$ dan $10 \times 20 \mathrm{~cm}$.

Menurut Rahayu dan Berlian (1996) dalam Affrida (2005), dalam budidaya bawang merah jarak tanam yang digunakan akan menentukan kepadatan populasi per satuan luas. Jarak tanam yang terlalu rapat atau tingkat kepadatan populasi yang tinggi akan mengakibatkan terjadinya persaingan antar tanaman dalam memperoleh air, unsur hara dan sinar matahari. Menurut Sitepu dkk. (2013), Pengaturan jarak tanam yang tepat untuk populasi yang besar sangatpenting untuk mendapatkan produksi optimum dan efisiensi pemupukan. Meskipun jumlah populasi besar, namun bila proses penyerapan unsur hara dan sinar mata hari tidak terganggu pada masa pertumbuhan, maka produksi akan tetap besar.

\section{KESIMPULAN}

1. Pertumbuhan bawang merah untuk jarak tanam $20 \times 15 \mathrm{~cm}$ dan $20 \times 20 \mathrm{~cm}$ memberikan hasil yang tinggi dibandingkan dengan perlakuan jarak tanam yang lain.

2. Pemberian pupuk kandang sapi belum mampu meningkatkan karakter pertumbuhan dan hasil tanaman bawang merah. 
3. Hasil umbi segar dan kering bawang merah per hektar terbanyak diperoleh pada tanaman dengan perlakuan jarak tanam $20 \times 15 \mathrm{~cm}$ dengan hasil 20,56 t/ha (umbi segar) dan 18,63 t/ha (umbi kering).

\section{DAFTAR PUSTAKA}

Hardjowigeno, S. 2010. Ilmu tanah. Akademika Pressindo, Jakarta.

Juwanda, M. 2011. Pertumbuhan, hasil dan efisiensi pemupukan nitrogen tanaman bawang merah pada pemberian dosis pupuk nitrogen serta pupuk kandang sapi. Tesis. Fakultas Pertanian, UNSOED.

Lasmini, S.A., Z. Kusuma, M. Santoso and A.L. Abadi. 2015. Application of organic and inorganic fertilizer improving the quantity and quality of shallot yield on dry land. International Journal of Scientific and Technology Research, 4(4): $243-$ 246.

Munawar, A. 2011. Kesuburan tanah dan nutrisi tanaman. IPB Press, Bogor.

Nugrahini, T. 2013. Respon tanaman bawang merah (Allium ascolonicum L. ) varietas tuk tuk terhadap pengaturan jarak tanam dan konsentrasi pupuk organik Nasa. $J$. Ziraa'ah, 36(1): 60 - 65.

Nurlaili. 2010. Respon pertumbuhan tanaman jagung (Zea Mays L.) dan gulma terhadap berbagai jarak tanam. J. Agronobis 2(4): $19-29$.
Plaster, E. J. 2007. Soil science and management. International Thomson Publishing Company. United States of America

Roidah, I. S. 2013. Manfaat penggunaan pupuk organik untuk kesuburan tanah. Jurnal Universitas Tulungagung Bonorowo 1(1): 30 42.

Sitepu, B.H, S. Ginting, dan Mariati, 2013. Respon pertumbuhan dan produksi bawang merah (Allium ascalonicum L. Var. tuk tuk) asal bijiterhadap pemberian pupuk kalium dan jarak tanam. Jurnal Agroteknologi 1(3): $711-724$.

Sumarni. N. dan A. Hidayat. 2005. Budidaya bawang merah. Balitsa, Bandung.

Sumarni. N, Rosliani. R dan Suwandi. 2012. Optimasi jarak tanam dan dosis pupuk NPK untuk produksi bawang merah dari benih umbi mini di dataran tinggi. J. Hort., 22 (2): 148 - 55.

Sumarno, 2007. Menjadikan teknologi revolusi hijau lebih ramah lingkungan dan berkelanjutan. Makalah Simposium dan Seminar Nasional Agronomi dan Kongres IX PERAGI, Bandung 15-17 November 2007.

Woldetsadik, K., 2003. Shallot (Allium cepa var. ascolonicum) responses to plant nutrients and soil moisture in a sub-humid tropical climate. Doctoral thesis. Swedish University of Agricultural Sciences Alnarp. 28p.

Zulkarnain, 2013. Budidaya tanaman tropis. Bumi Aksara, Jakarta. 